\title{
Energy Management System Audit and Implementation in Educational Buildings
}

\author{
${ }^{1}$ J. Nouri, ${ }^{2}$ A. R. Karbasi, ${ }^{2}$ R. Borgheipour and ${ }^{3}$ A. Taheri \\ ${ }^{1}$ Department of Environmental Health Engineering and Center for Environmental Research, \\ School of Public Health, Tehran University of Medical Science, Tehran, Iran \\ ${ }^{2}$ Graduate School of the Environment and Energy, Islamic Azad University, \\ Science and Research Campus, Tehran, Iran \\ ${ }^{3}$ Persia Energy Gostaresh Company (ESco), Tehran, Iran
}

\begin{abstract}
Concerning the high energy consumption of educational buildings in available study; it is conducted to estimate the energy consumption at the Faculty of Humanities (Building No. 2), Science and Research Campus (SRC) of the Islamic Azad University (IAU), Tehran, Iran. Auditing and implementing the energy management system in the implied building, efforts are finally made to propose managerial solutions towards reducing energy consumption in this building. After gathering data of the building, including quantity of energy consumption in a one-year period of study in 2005 and the energy consumption equipment in the building followed by a detailed data analysis, the overall energy consumption tendency is investigated in the building. As a result, it is found that the lightening system and electric motors of central heating system consumed the highest level of electricity energy and the highest thermal energy consumption due to boilers. By more analysis of the entire data, solutions are suggested for reducing the energy consumption used in lightening, central heating and cooling systems and boilers. A review of all the practical solutions for improving the systems available in the building showed that regarding the energy management matrix, the energy management system in the building stood at zero point, because the building lacked any operating unit under the title of 'Energy Management' which could monitor energy consumption at the university. Therefore, it is concluded that the energy efficiency in the building may be optimized to a certain extent by presenting a system for energy data collection, analysis and systematic implementation as well as a system for collection of basic information about energy-consuming equipment by means of measurement instruments. By providing this system, procedures are presented for optimizing energy consumption and saving in the building, while a management system and a complete information system are created at the same time. By employing the procedures described in the present study, 173,000 kilowatt-hours $(\mathrm{kWh})$ of power as well as 323642 cubic meters of natural gas can be saved per year.
\end{abstract}

Key words: Energy Management, Auditing, Consumption, Educational Buildings, Energy Saving, Energy Efficiency

\section{INTRODUCTION}

Iran is known as one of the richest countries in terms of fossil and renewable energies, while identified as one of the largest energy losers as well. Among the energy consumer parts, the buildings part is one of the basic consumers of energy, which uses $44 \%$ of whole energy consumption in Iran. Public and governmental departments consume $70 \%$ of this energy with low interest while educational buildings are participated in the same part ${ }^{[1]}$. Considering this fact, it is necessary to optimize the energy consumption and offer recommendation to reduce it. An energy management system is one of the most practical ways to optimize energy resources its aim is making optimum and rational use of energy at the lowest cost. Supplying suitable heat for residents is the main factor of energy consumption. In fact, adjusting an appropriate temperature such as air conditioning, and hot water supply account for a major part of energy consumption in any building; thus, it is very important to have complete recognition of the prevailing conditions in any building per energy consumption. Energy management and audit are considered as key measures toward optimization of energy consumption in any building, which allows distinguishing energy consumption in a building into such constituents as heating, cooling, ventilation, air conditioning, and hot water supplementary. To find out the level of every building position in terms of energy loss, it is required to have a specific procedure to analyse the building and identify the sources of loss. Thus, it is highly essential to implement an energy management system in every building ${ }^{[18][19]}$. The present study aimed at finding the source of uncontrolled energy loss in educational buildings. In this study, it would have been tried to estimate energy consumption at the Faculty of Humanities (Building No. 2), Science and Research Campus of the Islamic Azad University, in Tehran, Iran, in 2005 as well as providing some management solution to reducing energy consumption.

Corresponding Author: J. Nouri, Department of Environmental Health Engineering and Center for Environmental Research, School of Public Health, Tehran University of Medical Science, Tehran, Iran 


\section{DATA AND METHODOLOGY}

To investigate the energy consumption tendencies in building, first the characterization of the building anatomy and the cooling and heating systems are examined. The studied building is one of the buildings situated within the vast university complex of Science and Research Campus (SRC).The building is concreted structure and covers a total floor-space of 20,000 square meters in six floors, constructed in Phase 1 of the SRC. The population of the students has gradually changed and it's growing specifically during the year. Therefore, it cannot be considered a fixed population for the SRC. However, the population ceiling of the campus is considered as 20,000 students for the first five years, which increased to 50,000 students in the final phase of growth after expansion and development of the entire buildings. The average per capita space used by the instructors and students, including educational and other spaces, is calculated as 28-30 square meters, and regarding the total university area, per student is assumed 40 square meters spaces.

One of the most important parameters for energy loss investigating in a building is the kind of façade materials. The exterior coverage of the building is constructed using perforated bricks with a $20 \mathrm{~cm}$ thickness, and the façade stone has made of $5 \mathrm{~cm}$ thickness. Most of the outer surfaces included moisture insulators made up of 2 layers of felt and 3 layers of tar. prefabricated parts. Most of the windows are double glazing with plain panes having $6 \mathrm{~mm}$ thickness and are draped in the interior blind style. The window frames are entirely metal. The doors are mostly wooden and included $6 \mathrm{~mm}$ and $10 \mathrm{~mm}$ glasses ${ }^{[2][3]}$. The air conditioning systems in the building are included heating ventilation and cooling system, air washer (only on the sixth floor) and a heat pump used respectively for heating and cooling of most building spaces, amphitheatre, and the projector room on the sixth floor. There are radiators for heating lavatory spaces. The building's plant contained a number of equipment that their characteristics are shown as well in Table $1^{[5]}$. In the second stage of the energy consumption investigating trend in the building the entire energyconsuming equipment in the building are identified and studied. The equipment is divided into two groups of electrical and mechanical energy consumers. One of the major consumers of electrical energy in the building is the air conditioning system which their equipment is shown in Table 1.

Among the other consumers of electrical energy is the lightening system. To find out more about this matter, the lightening used in the building including the type and number of lights used in the entire spaces and rooms are investigated. The results are shown in Fig. 1 $[15][6]$.

Table 1: Equipment available in the building ${ }^{[5]}$

\begin{tabular}{|c|c|c|c|c|c|c|}
\hline System type & equipment & $\begin{array}{c}\text { Quantity } \\
\text { (set) }\end{array}$ & power & $\begin{array}{c}\text { Energy } \\
\text { use }\end{array}$ & unit & Consideration \\
\hline \multirow{3}{*}{ Heating system } & \multirow{2}{*}{ dual fuel boiler } & \multirow{2}{*}{2} & \multirow{2}{*}{-} & 310.05 & $\mathrm{~m} 3 / \mathrm{h}$ & Heating \& hot water \\
\hline & & & & 155.03 & $\mathrm{~m} 3 / \mathrm{h}$ & hot water supply in summer \\
\hline & hot water supply pump & 4 & 0.75 & 1671 & $\mathrm{kWh}$ & hot water supply in summer \\
\hline \multirow{4}{*}{ Cooling system } & chiller & 3 & 320 (ton) & 100800 & $\mathrm{kWh}$ & Cooling in summer \\
\hline & evaporator pump & 4 & $7.5 \mathrm{kWh}$ & 21600 & $\mathrm{kWh}$ & Cooling in summer \\
\hline & cooling tower pump & 4 & $22 \mathrm{kWh}$ & 63360 & $\mathrm{kWh}$ & Cooling in summer \\
\hline & cooling tower & & & 59400 & $\mathrm{kWh}$ & Cooling in summer \\
\hline \multirow{4}{*}{ Utility systems } & softening unit & 2 & 600 (lit) & - & - & Water treatment \\
\hline & firing pump & 3 & $3 \mathrm{kWh}$ & - & - & Firing system \\
\hline & storage tank pump & 3 & $11 \mathrm{kWh}$ & 7590 & $\mathrm{kWh}$ & Water storage \\
\hline & Exhaust fan & - & - & 18480 & $\mathrm{kWh}$ & - \\
\hline Fan coils & Fan coil electrical motor & - & - & 147301 & $\mathrm{kWh}$ & Heating \& cooling \\
\hline
\end{tabular}

The building's interior coverage consisted of

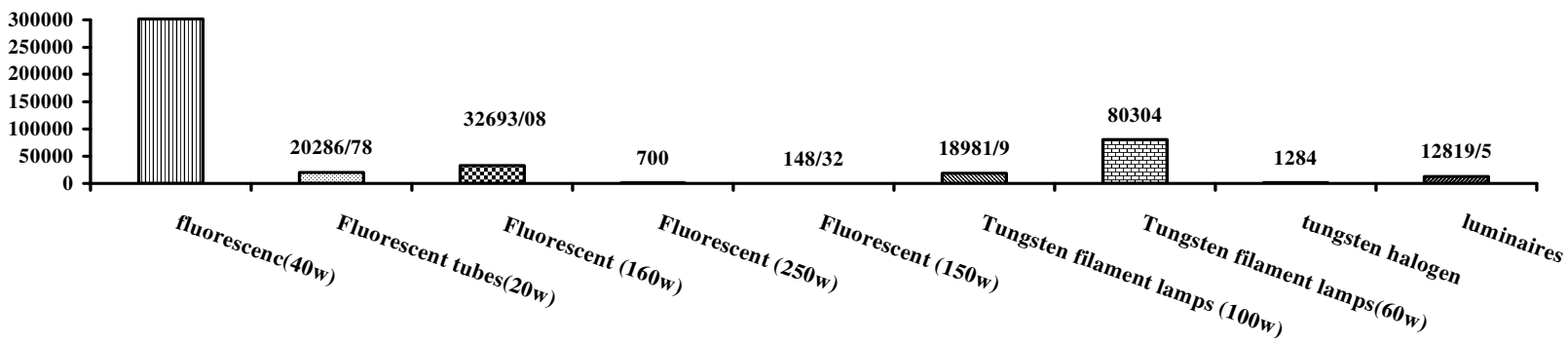

Fig. 1: Energy used by lightings in the building ${ }^{[15][6]}$ 
Office equipment and peripheral services also fell in the category of electrical energy consumers. Their number and consumption rates both were checked in the floors and then in the rooms of the building. The results are demonstrated in the Fig. 2. It must be told that the load of the operation of fan coil and air washer in investigation in order to determine the constituents of the energy consumption.

Boilers are the main thermal energy consuming equipment which accounted for the major consumption of the University's total fossil fuel.
They are used in the winter for both heating the building spaces and needed hot water, and in the summer, for needed hot water only. Concern the gas bills of the SRC, the amount of gas consumption by the campus is shown in Table 2. as well as in Tables 3 to 5, furthermore, the amounts of consumption and capacities of the boilers are estimated in hot and cold seasons and the timing of the boilers in the SRC and at the Faculty of Humanities (Building No. 2) in hot and cold seasons ${ }^{[18][20]}$.

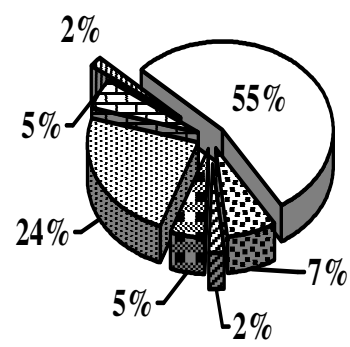

Fig. 2: Energy used split by functions in the building [15][6]

Table 2: Natural gas consumption by the SRC in hot and cold seasons as indicated in bill ${ }^{[18][20]}$

\begin{tabular}{cccc}
\hline season & Standard consumption $\left(\mathrm{m}^{3}\right)$ & $\begin{array}{c}\text { Running days in different } \\
\text { season }\end{array}$ & Daily consumption (m3/day) \\
\hline Hot season & 11910 & 210 & 57 \\
Cold season & 543439 & 120 & 4529 \\
\hline
\end{tabular}

Table 3: Energy used and capacities of boilers in the building in hot and cold seasons [ [ ${ }^{18][20]}$

\begin{tabular}{ccccc}
\hline season & quantity & type & NG $\left(\mathrm{m}^{3} / \mathrm{h}\right)$ & H.W. Flow rate $($ ton/h) \\
\hline Cold season & 2 & burner & 310.05 & 49.18 \\
Hot season & 1 & burner & 155.03 & 24.59 \\
\hline
\end{tabular}

Table 4: Boilers time running throughout Science \& Research Campus ${ }^{[18][20]}$

\begin{tabular}{cccc}
\hline \multirow{2}{*}{ season } & Energy usage $\left(\mathrm{m}^{3} / \mathrm{h}\right)$ & Daily Consumption as indicated in bill $\left(\mathrm{m}^{3} / \mathrm{d}\right)$ & Boiler running Time $(\mathrm{h} / \mathrm{d})$ \\
\hline Cold season & 1239.71 & 4528.66 & 3.65 \\
Hot season & 354.31 & 57.00 & 0.16 \\
\hline
\end{tabular}

Table 5: Boilers time running in the building in hot and cold seasons ${ }^{[18][20]}$

\begin{tabular}{|c|c|c|c|c|c|c|c|c|c|c|c|}
\hline season & $\begin{array}{c}\text { Percentag } \\
\text { e of } \\
\text { througho } \\
\text { ut the } \\
\text { SRC }\end{array}$ & $\begin{array}{c}\text { Daily } \\
\text { Consumptio } \\
\mathrm{n} \text { bill }\left(\mathrm{m}^{3} / \mathrm{d}\right)\end{array}$ & $\begin{array}{c}\text { Energy } \\
\text { usage } \\
\left(\mathrm{m}^{3} / \mathrm{h}\right)\end{array}$ & $\begin{array}{l}\text { Boiler } \\
\text { time } \\
\text { runnin } \\
(\mathrm{h} / \mathrm{d}) \mathrm{g}\end{array}$ & $\begin{array}{l}\text { Neede } \\
\text { d Hot } \\
\text { water }\end{array}$ & $\begin{array}{c}\text { Fuel } \\
\text { GCV } \\
\text { (kjoule/m³) }\end{array}$ & $\begin{array}{c}\text { Fuel } \\
\text { density } \\
\left(\mathrm{kg} / \mathrm{m}^{3}\right)\end{array}$ & $\begin{array}{c}\text { Fuel } \\
\text { GCV } \\
\text { (kjoule/kg) }\end{array}$ & $\begin{array}{c}\text { Needed } \\
\text { Hot } \\
\text { water } \\
\text { enthalpy } \\
80^{\circ} \\
\text { (kjoule/kg) }\end{array}$ & $\begin{array}{c}\text { Hot } \\
\text { water } \\
\text { return } \\
\text { enthalpy } \\
45^{\circ} \\
\text { (kjoule } / \mathrm{kg} \text { ) }\end{array}$ & $\begin{array}{l}\text { Quantity } \\
\text { of gas } \\
\text { consumed } \\
\left(\mathrm{m}^{3} / \mathrm{h}\right)\end{array}$ \\
\hline $\begin{array}{c}\text { Cold } \\
\text { season }\end{array}$ & 25.01 & 1133 & 310.05 & 3.65 & 179.65 & 39490.7 & 0.73 & 54096.9 & 335.52 & 189.18 & 310.05 \\
\hline $\begin{array}{c}\text { Hot } \\
\text { season }\end{array}$ & 43.76 & 25 & 155.03 & 0.16 & 3.96 & 39490.7 & 0.73 & 54096.9 & 335.52 & 189.18 & 155.03 \\
\hline
\end{tabular}


The quantity of hot and cold water used for heating and cooling system in the building is studied to take into account the major consumption of thermal energy related to the interior spaces heating in the cold seasons, and the major consumption of electrical energy related to the interior spaces cooling in the hot seasons due to the energy loss of the interior spaces. As a result, it is understood that the highest consumption of hot water in the hot and cold seasons is in the ground floor. Figs. 3 and 4 show the hot water consumption in the building floors in the hot and cold seasons.

The third stage of investigating the energy consumption trend is identified for the high consuming equipment. For this purpose, the consumption of all floors is calculated, which its summary of rates is shown in Fig.5 in order to accelerate the result understanding the highest consumption of electrical energy is due to the lightening system and the load resulting of office equipment and services as well as the highest consumption of natural gas the boilers. Therefore, considering the increasing of fuel prices and equally consumption in the building, these parts are chosen to undergo total energy audit.

\section{RESULTS AND DISCUSSION}

After collecting all the required data related to the building such as energy consumption and energyconsuming equipment and analysing the data, the overall energy consumption tendency of at the Faculty of Humanities (Building No. 2), the highest consumption of electrical energy related to the lightening system and the electric motors of the central heating systems and the highest consumption of thermal energy to the boilers, practical solutions and procedures were provided for both electrical and thermal categories. Before delineating the solutions, it is quite necessary that the issue of energy management dealt with the economic perspective, i.e. the most important step of initiating these measures motivation, in order to show the importance of the issue. As the total power consumption in 2004 amounted to 8 million $\mathrm{kWh}$, costing nearly $53894 \$$, the same total power consumption in 2011 is estimated to cost 101078 \$, i.e. 1.9 times the current cost, given the upward trend of fuel prices (Fig. 6) ${ }^{[15][6] .}$

Moreover, the total natural gas consumption in 2004 amounted to 550,000 cubic meters at an approx. cost of 4272 \$ while the same consumption in 2011 will cost $10624 \$$ or nearly 2.5 times of the current cost. These figures provide a much clearer picture of the importance of energy optimization (Fig. 7).

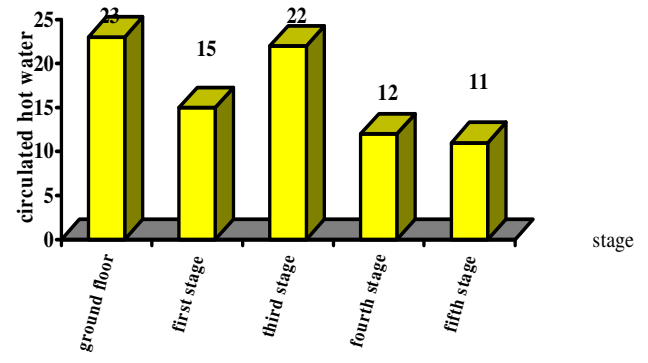

Fig. 3: Cold water demand in different stages during the warm season ${ }^{[5][6]}$

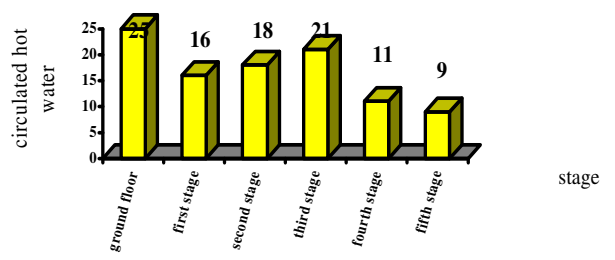

Fig. 4: Hot water demand in different stages during the cold season ${ }^{[5][6]}$

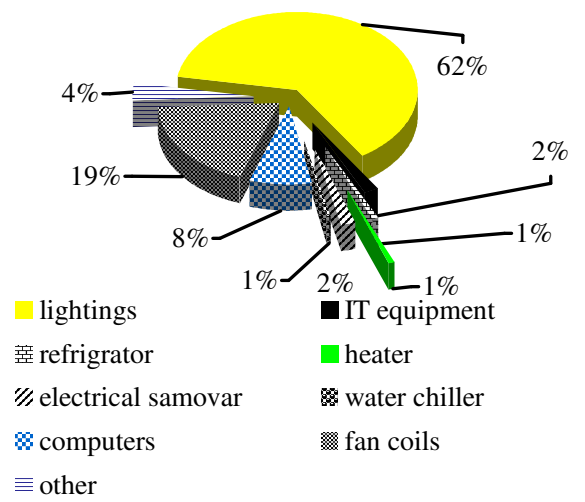

Fig 5: Energy used split by function in the different stories of the building ${ }^{[6][11]}$

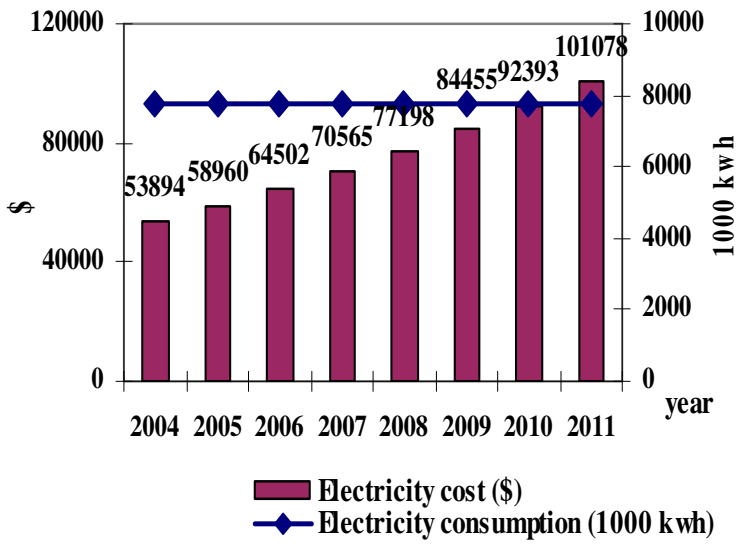

Fig. 6: Electricity costs assuming fixed consumption in coming years ${ }^{[6][11]}$ 


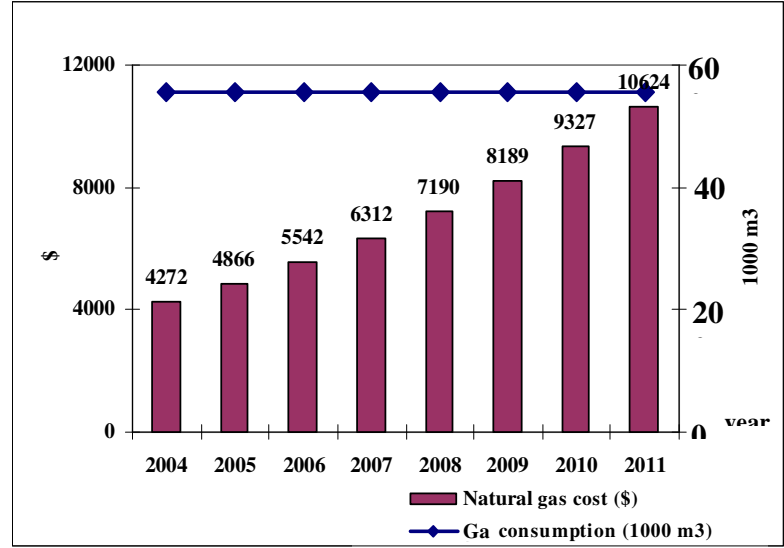

Fig. 7: Natural gas costs assuming fixed consumption in coming years ${ }^{[11]}$

\section{Solutions provided for reducing electrical energy consumption}

1. Replacement of low consumption bulbs: Considering their purchase prices and installation cost, low consumption light bulbs reduce the cost of energy to one fifth. There are 571 filament bulbs in the building which use up $115,904 \mathrm{kWh}$ of electricity which their replacing by low consumption bulbs, decrease the expanses around $86,928 \mathrm{kWh}$.

2. Use of photocells: Regarding this fact that a considerable amount of energy is lost in the halls, corridors and lavatories, photocells can be used to prevent such losses. Of course, it is practically impossible to use light sensors in the halls and corridors during 9 months of the academic year because such spaces mostly are occupied by individuals and students. By installing such equipment in the halls and corridors in the summer and in the lavatories for the whole year, the electrical energy will be saved nearly $13,128 \mathrm{kWh}$ and 58,000 $\mathrm{kWh}$. To calculate the cost of the required photocells, the number and layout of lights in all the floors, number of photocells and areas, needed for each zone are investigated. The results showed that the number of photocells required for the corridors/halls and lavatories are 318 and 60, costing about 836 and 502 dollar respectively ${ }^{[6][14]}$.

3. Use of thermo switches and thermostatic valves: By the use of such equipment power consumption by central heating systems will be reduced around $8 \%$ $10 \%$, resulting energy consumption saving of $14,730 \mathrm{kWh}$ in the building ${ }^{[10] .}$

4. Potential use of solar energy to generate electricity in the building: Following thorough investigations, it is found that the use of photovoltaic solar systems in the building, despite being one of the best power generation means, would not prove economical because of their high prices (each 45 -watt module costs \$400), and is eliminated from the study [16].

\section{Solutions provided for reducing thermal energy consumption}

1. Precise regulation of the boilers: Taking into account that the building's boilers had very low efficiency, the potential gas consumption saving is calculated on this assumption of the increased efficiency in hot and cold seasons. As a result, the amounts are estimated at $132.66 \mathrm{~m}^{3} / \mathrm{h}$ and 66.34 $\mathrm{m}^{3} / \mathrm{h}$. In this way, the efficiency case of all boilers is increased in the building, therefore there will be an estimated total saving of $60,000 \mathrm{~m}^{3}$ of natural gas (Table 6) ${ }^{[20] .}$

2. Applying the standard rules of in the building: To reduce thermal energy consumption for heating and cooling purposes and investigating the potential savings, two rooms in the south western section of the building are chosen, which represents the types of rooms by different conditions, and their total heat losses are calculated. Comparing the heat losses with the energy consumption standard under the current rooms' conditions, the excess heat loss arising from non-compliance to the obtained standard. The results showed that Faculty of Humanities (Building No. 2) had nearly 12\% more heat losses than Ashrea standard for a building with the same specifications. It can be compensated by providing practical solutions such as adding an interior layer of insulation, an exterior layer of insulation or an acoustic layer (owing to the educational nature of the building) for this losses (Table 7) ${ }^{[7][13]}$. There are two hot water coils in the building which consume 0.352 cubic meters per min of hot water. Based on the conducted measurements and the operation time in one hour, it is found that hot water consumption approximately is amounted to 39.37 tons a day in winter. The remaining hot water is used for heating the building spaces. Provided that the relevant building standards are complied with, nearly 12738.9 cubic meters of natural gas will be saved in the cold seasons (Table 8).

3. Use of solar energy for heating and needed hot water: The most appropriate system for solar needed hot water in the building is found to be indirect heating systems for hot water. According to the volume of hot water used in the building and the number of required collectors are calculated. It is notable that such systems should be used for needed hot water, because they are not economic to use for heating purposes given the large dimensions of the educational complex. As indicated boiler calculations, the volume of hot water supplied in winter, which is entirely used for heating water (to $80^{\circ} \mathrm{C}$ ), is as Table 9. 
Table 6: Potential savings on the building's boilers in hot and cold season ${ }^{\text {[20] }}$

\begin{tabular}{cccccc}
\hline Season & $\begin{array}{c}\text { Current performance } \\
(\end{array}$ & $\begin{array}{c}\text { Current fuel } \\
\text { consumption } \\
\left(\mathrm{m}^{3} / \mathrm{h}\right)\end{array}$ & $\begin{array}{c}\text { Fuel consumption after } \\
\text { improved }\left(\mathrm{m}^{3} / \mathrm{h}\right)\end{array}$ & $\begin{array}{c}\text { Energy Saving in cold } \\
\text { season }\left(\mathrm{m}^{3} / \mathrm{h}\right)\end{array}$ & $\begin{array}{c}\text { Energy saving } \\
\left(\mathrm{m}^{3}\right)\end{array}$ \\
\hline Cold season & 58.78 & 310.05 & 177.39 & 132.66 & 58105.08 \\
Hot season & 58.78 & 155.03 & 88.69 & 66.34 & 2229.024 \\
\hline
\end{tabular}

Table 7: Excess heat loss due to non-compliance with standards ${ }^{[7][13]}$

\begin{tabular}{|c|c|c|c|c|c|c|}
\hline season & room & $\begin{array}{l}\text { Total lost heat for } \\
\text { studied room } \\
(\mathrm{Btu} / \mathrm{h})\end{array}$ & $\begin{array}{l}\text { studied room } \\
\left(\mathrm{ft}^{3}\right) \text { volume }\end{array}$ & $\begin{array}{c}\text { Lost heat for studied } \\
\text { room } \\
\left(\mathrm{Btu} / \mathrm{ft}^{3} \mathrm{~h}\right)\end{array}$ & $\begin{array}{l}\text { Total lost heat for } \\
\text { typical room } \\
\left(\mathrm{Btu} / \mathrm{ft}^{3} \mathrm{~h}\right)\end{array}$ & $\begin{array}{c}\text { Excess lost heat due to } \\
\text { non- observance } \\
\text { standards \% }\end{array}$ \\
\hline Hot & 1 & 11468 & 7219 & 1.5885 & 1.38 & 13.13 \\
\hline season & 2 & 11886 & 7175 & 1.6566 & 1.45 & 12.47 \\
\hline Cold & 1 & 22529 & 7219 & 3.12 & 2.71 & 13.14 \\
\hline season & 2 & 17151 & 7175 & 2.3904 & 2.1 & 12.15 \\
\hline
\end{tabular}

Table 8: Potential saving in the building on heating and cooling parts [ ${ }^{20]}$

\begin{tabular}{|c|c|c|c|c|c|c|c|c|}
\hline $\begin{array}{l}\text { Total boilers } \\
\text { discharged hot } \\
\text { water }\end{array}$ & $\begin{array}{r}\text { Hot water } 1 \\
\mathrm{cc}\end{array}$ & $v$ rate for & $\begin{array}{l}\text { Running time } \\
\text { (day+ night) }\end{array}$ & $\begin{array}{l}\text { Hot water } \\
\text { flow rate } \\
\text { for coils }\end{array}$ & $\begin{array}{c}\text { Hot water } \\
\text { needed for } \\
\text { heating }\end{array}$ & $\begin{array}{c}\text { N.G } \\
\text { consumpti } \\
\text { on }\end{array}$ & N.G saving & $\begin{array}{c}\text { Total N.G } \\
\text { saving }\end{array}$ \\
\hline (ton/h) & $\left(\mathrm{M}^{3} / \mathrm{min}\right)$ & (ton/h) & $(\mathrm{min} / \mathrm{h})$ & $(\operatorname{ton} / \mathrm{d})$ & (ton/h) & $\left(\mathrm{M}^{3} / \mathrm{d}\right)$ & $\left(\mathrm{M}^{3} / \mathrm{d}\right)$ & $\left(\mathrm{M}^{3} / 120 \mathrm{~d}\right)$ \\
\hline 179.65 & 0.352 & 20.55 & $3+0.5$ & 39.37 & 145.2 & 884.64 & 106.157 & 12738.9 \\
\hline
\end{tabular}

Table 9: Hot water volume used on coils in the building ${ }^{[16]}$

\begin{tabular}{|c|c|c|c|c|}
\hline (Ton/d) & $(\mathrm{kg} / \mathrm{d})$ & $(\mathrm{L} / \mathrm{d})$ & $\left(\mathrm{M}^{3} / \mathrm{d}\right)$ & $(\mathrm{Gal} / \mathrm{d})$ \\
\hline 3.96 & 3960 & 4069.89 & 4.069 & 5.15 \\
\hline \multicolumn{5}{|c|}{ Table 10: The total collector surface required for the building ${ }^{[16]}$} \\
\hline $\begin{array}{l}\text { Needed } \\
\text { hot water }\end{array}$ & $\begin{array}{c}\text { Collector } \\
\text { area }\end{array}$ & $\begin{array}{c}\text { Collector } \\
\text { cost }\end{array}$ & $\begin{array}{c}\text { Storage tank, } \\
\text { exchanger, } \\
\text { control }\end{array}$ & $\begin{array}{c}\text { Total } \\
\text { cost }\end{array}$ \\
\hline (L/d) & $\left(\mathrm{m}^{2}\right)$ & (\$) & $(\$)$ & (\$) \\
\hline 4069.89 & 18.61 & 1861 & 5000 & 6861 \\
\hline \multicolumn{5}{|c|}{ Table 11: Energy saving in systems and equipment } \\
\hline $\begin{array}{c}\text { energy } \\
\text { consuming } \\
\text { Elements }\end{array}$ & \multicolumn{2}{|c|}{ Energy used } & & \\
\hline \multirow{2}{*}{ lighting } & \multicolumn{2}{|c|}{86928 (kwh) } & \multicolumn{2}{|c|}{ Using efficient lamps } \\
\hline & \multicolumn{2}{|c|}{ 71143(kwh) } & \multicolumn{2}{|c|}{ Using photo cell } \\
\hline Fan coil & \multicolumn{2}{|c|}{14730 (kwh) } & \multicolumn{2}{|c|}{ Inside temperature control } \\
\hline \multirow{3}{*}{ boilers } & \multicolumn{2}{|c|}{$271810\left(\mathrm{~m}^{3}\right)$} & \multicolumn{2}{|c|}{$\begin{array}{l}\text { Improving boiler } \\
\text { performance }\end{array}$} \\
\hline & \multicolumn{2}{|c|}{$11910\left(\mathrm{~m}^{3}\right)$} & \multicolumn{2}{|c|}{$\begin{array}{l}\text { Applying Flat plate } \\
\text { collectors }\end{array}$} \\
\hline & \multicolumn{2}{|c|}{$27183\left(\mathrm{~m}^{3}\right)$} & \multicolumn{2}{|c|}{$\begin{array}{l}\text { Applying Thermostatic } \\
\text { valve }\end{array}$} \\
\hline $\begin{array}{l}\text { Heating \& } \\
\text { cooling }\end{array}$ & \multicolumn{2}{|c|}{$12739\left(\mathrm{~m}^{3}\right)$} & \multicolumn{2}{|c|}{ Applying building standard } \\
\hline
\end{tabular}

A solar collector is selected as sample, to find out the amount of collector surface needed for the building during a hot season. Such a collector can easily rise the temperature of the fluid running in the exchanger to $80^{\circ}$ $\mathrm{C}$, and provide 49.21 to $56.78 \mathrm{~L}$ of hot water per hour with a surface of 2.7 square meters. Therefore, the required collector surface is calculated, by offering the specifications of the sample collector. To estimate the solar system's hot water cost, the prices of the collectors (100 dollar per $\mathrm{m}^{2}$ ), reservoir tank (89 dollar per 1140 L), control systems (2222 dollar per building), and exchangers (2777 dollar per building) are inquired from the State Organization for Optimization of Fuel Consumption, and the following results are obtained in Table 10. It can be therefore concluded that it can be stopped the use of the boilers completely in the summer for the needed hot water, thereby, it will be saving 155.03 cubic meters per hour of natural gas.

\section{CONCLUSION}

This study, after preliminary identification of energyconsuming systems used in the building and prioritizing and classifying consumption, energy audits are conducted in the main categories and the relevant reports are prepared. The procedure for carrying out this project is as follows:

- Identifying energy-consuming equipment based on their use

- Classifying energy-consuming equipment and identifying important and basic parameters for measurement

- Classifying equipment based on their electrical and thermal function

- Arranging priorities for conducting measurements based on major energy-consuming equipment 
- Preparing data collection forms to gather effective and important data which are used in calculations quickly and correctly

- Collecting information besides recognizing operation time duration of different equipment to be used in calculation of savings

- Conducting the calculations and analysis of data acquired

- Classification of saving chances into three expanses format (high, low and average expanse)

- Presenting energy management system's documents, regarding represented requirement in a building

- Formulating data collection and analysis methods

- Presenting instructions and energy management procedures

- Indicating the importance of investment in certain sections of the building

- As the highest electricity consumption related to the light system and electric motors of the central heating systems and the highest thermal energy consumption of boilers, it seemed quite necessary to provide solutions for reducing electrical and thermal energy consumption. Table 11 shows the amount of energy saved in different systems and equipment and the methods of reducing energy consumption in them.

Considering all practical solutions for improving the available systems in the building, it is finally concluded that the energy officials should create an appropriate statistical system in order to attain the energy saving goals in the building. Such a system would enable officials to easily make decisions about energy issues by analysing the documents. As the energy management system in the building stands at zero point, energy consumption in the building may be reduced to a certain extent by providing a system for energy data collection, analysis and systematic implementation as well as a system for collection of major and basic information about the energy-consuming equipment using measurement instruments. In this respect, certain solutions seem to be necessary, some of which are described below:

- Organizational information dissemination at the university through posters,

announcements, and internal conferences at the lowest cost.

- Installing simple measurement systems for measuring certain basic parameters such as amount of gas consumption, electricity consumption, and hot water in each college separately.
- Accurate regulation of the boilers, contributing active consultants in this field, which is easily possible.

- Using remote control systems in elevators which reduce energy consumption by $20 \%$ at the lowest cost.

- Using photocells in places where movement is limited.

- Installing and accurately regulating thermo switches of central heating systems which are not functioning properly at the moment.

- Installing thermostatic valves which cost little but save a lot in hot water consumption.

- Using insulators and other certain equipment to prevent intrusion of cold air and reducing losses.

- Considering mechanical air-conditioning system application in some parts of sections

\section{REFERENCES}

1. 1iranian Fuel Conservation Organization, 1381, the second international congress' articles collection of optimizing energy consumption in building, IR international congress center

2. Architecture Plan, Electrica and mechanical structures, Faculty of Humanities (Building No. 2), 1373, Iran Amayesh consultant engineers

3. Tavan Danaie particular publication, first issue, Bahman-1377, acquiring with Science and Research Campus of Islamic Azad University, congress department of considering functions and services of Islamic Azad University

4. A strategic approach to energy and environmental management, (2004). Queen's Printer and Controller of HMSO. 20-36

5. Applications Manual (AM) 10, natural ventilation in non-domestic buildings, (1997). Chartered Institution of Building Services Engineers, CIBSE, London. 1218.

6. Bertoldi, P., Ricci, A., de Almeida, A., (2001). Energy efficiency in household Appliances and lighting, Library of congress cataloguing in publication Data Die Deutsch Bibliothek-CIPEinheitsaufnahme.

7. Building Research Establishment, A developer's guide to environmentally smart buildings, Good Practice Guide 258, (1994). BRE, Garston. (BRECSU), BRE Publication, Garston, Watford, WD2 7JR. 11-15.

8. Building Research Establishment, Developing an effective energy policy, Good Practice Guide 186, (1994). BRE, Garston. (BRECSU), BRE Publication, Garston, Watford, WD2 7JR. 4-20.

9. Building Research Establishment, Energy efficiency in offices. Low cost major refurbishment. Policy Studies Institute, 100 Park Village East, London NW1, Good Practice Case Study 1, (1994). BRE, Garston. (BRECSU), BRE Publication, Garston, Watford, WD2 7JR. 
10. Building Research Establishment, Energy efficiency in offices. One Bridewell Street, Bristol. A new high quality air conditioned office with low energy costs, Good Practice Case Study 21, (1994). BRE, Garston. (BRECSU), BRE Publication, Garston, Watford, WD2 7JR. 7-15

11. Building Research Establishment, Energy use in offices, Energy Consumption Guide 19, (1994). BRE, Garston. (BRECSU), BRE Publication, Garston, Watford, WD2 7JR. 6-24

12. Building Research Establishment, Natural ventilation in no domestic buildings, BRE Digest 399, (1994). BRE, Garston. (BRECSU), BRE Publication, Garston, Watford, WD2 7JR. 7-10.

13. Building Research Establishment, The Elizabeth Fry Building, University of East Anglia - feedback for designers and clients, New Practice Final Report 106, (1994). BRE, Garston. (BRECSU), BRE Publication, Garston, Watford, WD2 7JR. 516.

14. Electric Power Research Institute, ( 2000). Energy Management System (Technical Brief TB. EMU. 121.4.87), CA. available at: www.epri.com

15. Energy Consumption Guide 19, Energy use in offices, (2000), Energy Efficiency Best Practice program, DETR, London.
16. Greening federal facilities, U.S, (2001). Department of Energy Office of Energy Efficiency and Renewable Energy Management Program, $2^{\text {nd }}$ Ed. Queen's Printer and Controller of HMSO, The Faraday Partnership for the Integration of New and Renewable Energy in Buildings (INREB). 12-16.

17. Refurbishment of air-conditioned buildings for natural ventilation, Technical Note (TN) 8/98, (1998). Building Services Research and Information Association, BSRIA Publication, Berkshire.

18. Thumann, A., Younger, W. J., (2003). Handbook Energy Audits, $6^{\text {th }}$ Ed. Published by the Fairmont Press, Inc. Lilburn, Georgia. available at: http: // Fairmont Press.com

19. TURNER, W. C., (2001). Energy Management Handbook, $4^{\text {th }}$ Ed. Published by the Fairmont Press, Inc. Lilburn, Georgia. available at: http: // Fairmont Press.com

20. Wulfinghoff, D. R. (1999). Energy Efficiency Manual, Energy Institute Press. 